\title{
Jatkuvaa oppimista osaamismerkein tutkinto- ja oppilaitosrajat ylittäen
}

\author{
Digitaaliset osaamismerkit ovat yhä suositumpi tapa \\ tunnistaa ja tunnustaa osaamista. Merkeille on luotava \\ ja vakiinnutettava pelisäännöt, jotka selventävät \\ niiden arvon niin oppijalle kuin oppilaitokselle ja \\ työelämän edustajalle.
}

TYÖELÄMÄSSÄ VAADITTU OSAAMINEN vaihtelee työuran eri vaiheissa työtehtävien ja niissä tarvittavien tietojen ja taitojen suhteen (Billett 2001; Ellström 1997). Digitalisaatio muuttaa työelämän lisäksi tapoja tarjota ja toteuttaa koulutusta. Parlamentaarinen jatkuvan oppimisen uudistus (Opetus- ja kulttuuriministeriö, OKM 2020) painottaa työikäisten kohdennettua osaamisen kehittämistä. Se edellyttää uutta, työelämälähtöistä ja monimuotoista koulutustarjontaa. Osaamista tulee voida hankkia ja kerryttää yhä useammasta lähteestä. Jatkuvan oppimisen digitaalinen ekosysteemi voi olla tulevaisuuden ratkaisu, joka kokoaa osaamisinformaation helppokäyttöiseen muotoon ja palvelee sekä kansalaisia että työelämää (OKM 2020). Palvelukehityksen keskiössä ovat sovellukset, joiden avulla kartoitetaan, tunnistetaan ja tunnustetaan osaamista (OKM 2019).

Digitaaliset osaamismerkit (digital open badge) kasvattavat suosiotaan tapana tunnistaa ja tunnustaa eri tavoin hankittua osaamista. Kuvaan, mitä osaamismerkit ovat ja miten jatkuvaa oppimista voidaan hahmottaa niiden avulla. Nojaan tarkastelussa aiempaan tutkimukseen osaamismerkein ohjautuvasta oppimisesta (Brauer 2019; Brauer, Kettunen, \& Hallikainen 2018), osaamisperusteisuudesta ja koulutuksen työelämäläheisyydestä (Brauer \& Pajarre ym. 2020). Lisäksi hyödynnän kokemuksia kehittämishankkeista. Kuvaan kehitystyön tuloksia jatkumona ja hahmottelen osaamismerkkijärjestelmien tulevaisuuden näkymiä suhteessa koulutuspoliittisiin tavoitteisiin (OKM 2019; 2020) ja kehittyviin yhteiseurooppalaisiin käytänteisiin (OECD 2020).

\section{DIGITAALISET OSAAMISMERKIT}

Osaamismerkit ovat monelle tuttuja esimerkiksi partiosta tai varusmiespalveluksesta. Digitaaliset merkit saivat alkunsa massiivisista verkkokursseista, 
MERKIN LUOTETTAVUUdEN

ARVIOINTIA VOIDAAN

EDIST $\ddot{A}$ MUOTOILEMALLA

HUOLELLISESTI

OSAAMISTAVOITTEET JA

ARVIOINTIKRITEERIT.

mooceista, ja nykyään ne voidaan avointen rajapintojen (API) kautta integroida niin erilaisiin oppimisympäristöihin kuin opintohallinnon kokonaisarkkitehtuuriratkaisuihin (Brauer 2019). Merkkien hallinnointiin käytettävät tekniset sovellukset perustuvat samaan sertifioituun Open Badges -standardiin (Open Badges Community 2020), joka mahdollistaa merkkien sisältämän datan liittämisen erilaisiin järjestelmiin ja muun muassa oppimisanalytiikan monimuotoisen hyödyntämisen.

Digitaalinen osaamismerkki on konkreettinen sähköinen todiste osaamisesta. Yksittäisen merkin rakenteeseen kuuluvat tieto osaamistavoitteista, joiden mukaista osaamista hakija on halunnut tunnistettavan, ja arviointikriteeri, jonka perusteella osaaminen on tunnustettu (Brauer 2019).

Merkkien laajuutta voidaan kuvata puhumalla yksittäisiä osaamisia kuvaavista mikromerkeistä (microcredentials) sekä niitä laajempien kokonaisuuksien, kuten kokonaisten kurssien, makromerkeistä (macrocredentials). Metamerkit puolestaan ovat osaamismerkkijärjestelmän erilaisista saavutuksista (milestones) automaattisesti myöntämiä merkkejä, joilla tuetaan esimerkiksi oppimisen pelillistämistä (Brauer 2019). Osaamismerkeillä voidaan kuvata toivottua osaamista tarkemmin kuin opetussuunnitelmilla (Brauer, Pajarre ym. 2020). Osaaminen voi käsittää esimerkiksi alakohtaisen ammattiosaamisen ja työelämässä tarvittavan geneerisen osaamisen (Chan 2016).

Digitaaliset osaamismerkit ovat yksi mahdollisuus fasilitoida ja kehittää oppimisprosessia, ohjausta ja arviointia (Brauer 2019). Niiden osaamistavoitteet ja arviointikriteerit auttavat merkin hakijaa ymmärtä- mään, millaista osaamista työelämässä tarvitaan sekä arvioimaan omaa suoritustaan ja hahmottamaan omaa osaamistaan kokonaisuutena. Merkin hakijan tehtävä on osoittaa osaamista käytännönläheisesti, merkin edellyttämällä tavalla. Palaute ohjaa kehittämään osaamista edelleen.

Osaamismerkkien visuaalinen kokonaisuus auttaa henkilökohtaisen opintopolun suunnittelussa, ja ansaitut merkit havainnollistavat etenemistä. Osaamismerkein ohjautuvassa oppimisessa yksilöllinen kehittymissuunnitelma on päivittyvä ja ajantasainen sekä opintojen aikana että työelämässä. Merkin myöntäjä ja samalla osaamisen tunnistaja ja tunnustaja voi olla oppilaitos, yritys tai järjestö.

Digitaalisilla osaamismerkeillä on tarkoitus tehdä oma osaaminen näkyväksi myös muille, joten on tärkeää, että merkki on visuaalisesti kiinnostava, informatiivinen ja sisältää yksityiskohtaisen tiedon merkin myöntäjästä (Brauer 2019). Osaamismerkkien todistuksia monipuolisemmat osaamiskuvaukset edistävät merkin saajan, työelämän, oppilaitoksen ja koulutuksen kehittäjien välistä vuoropuhelua (Brauer, Siklander, Impiö \& Vuopala 2020). Kuten osaamisen tunnistamisen ja tunnustamisen rakenteita tutkineet Olli Oosi ja kumppanit (2020) toteavat, on "osaamisen tunnistamisen ja tunnustamisen kaikissa käsitteissä ja niihin liittyvissä työkaluissa kysymys yhteiskunnan eri toimijoiden välisestä vuorovaikutuksesta" (mt., 59).

Osaamismerkkien kehitystyössä keskustelua herättää muun muassa merkkien luotettavuus, kun kuka tahansa voi luoda ja myöntää merkkejä (Brauer 2019). Hämmennystä ovat herättäneet esimerkiksi hankkeissa tehdyt kokeilut, joissa merkkejä on myönnetty monenlaisin perustein, ilman perusteita ja eri organisaatioiden toimesta. Digitaaliset merkit ovat uusia monessa oppilaitoksessa, ja onkin tarpeen kokeilla niiden hallinnointia ja niitä koskevia sovelluksia. Kaikki digitaaliset merkit eivät kuitenkaan ole osaamismerkkejä.

Digitaalisilla merkeillä voidaan dokumentoida osallistumista koulutustapahtumiin, jolloin kaikki paikalla olleet saavat merkin automaattisesti. Osallistumismerkki kertoo kuitenkin vain, mihin tilaisuuteen sen saaja on osallistunut eikä kuvaa, mil- 
laista osaamista tällä on (Brauer 2019). Digitaalinen merkki voi olla muodoltaan myös määräaikaiseen voimassaoloon perustuva sertifikaatti tai diplomi, joka korvaa todistukset. Osaamismerkin metatietojen tulee kuvata selvästi, millaista osaamista merkin saaminen edellyttää. Merkin luotettavuuden arviointia edistää se, kun osaamistavoitteet ja arviointikriteerit muotoillaan huolellisesti ja sallitaan merkin saajalle mahdollisuus liittää osaamisen osoittamisen todisteet merkkiin (Brauer, Siklander ym. 2020). Erilaiset merkit vaikuttavatkin oppimiseen eri tavoin. Osaamismerkin saaminen voidaan kokea esimerkiksi kannustuksena, tunnustuksena tai saavutuksena mutta myös ulkoisena palkintona, joka ei tue oppimista (Brauer ym. 2018)

\section{KANSALLISET OSAAMISMERKKIJÄRJESTELMÄT}

Suomessa digitaalisia osaamismerkkejä on kehitetty ja tutkittu 2010-luvulta lähtien. Merkit ovat kuitenkin yhä nouseva ilmiö, jota kuvaa tarve yhteisille kansallisille ja kansainvälisille käytänteille. Vaikka osaamismerkkejä koskevan tutkimuksen keskiössä ovat merkkien vaikutukset oppimiseen, käytännössä nousevat usein esille koulutuspoliittisesti kiinnostavat kysymykset, kuten 1) kuinka varmistetaan merkkien luotettavuus ja laatu, 2) miten ja millaiset merkit tukevat sujuvia siirtymiä tutkinto- ja oppilaitosrajojen yli, 3) miten merkit mahdollistavat osaamiskuvausten käsittelyn erilaisissa teknisissä järjestelmissä ja 4) millaisia kansallisia tai eurooppalaisia linjauksia on tulossa ja milloin.

Haasteiden ratkaisemiseksi ja tiedon jakamiseksi on käynnistetty kansallisia kehittämishankkeita, joissa on kehitetty jonkin tietyn osaamisen tai osaamiskokonaisuuden osaamismerkkejä. Vaikka tuotokset näyttäytyvät ensisijaisesti tehtyinä merkkeinä ja merkkijärjestelminä, yhteistyössä on ratkottu niitä laajempia kysymyksiä ja selvitetty esimerkiksi merkkien laadunvarmistusta, osaamiskuvausten ja teknisen metadatan kansallista tai kansainvälistä liikkuvuutta sekä tuotettu organisaatioiden yhteisiä hallintamalleja.

Jatkuvan oppimisen digitaalisen ekosysteemin kehitysnäkökulmasta yhteiset järjestelmät ja hallintamallit ovatkin tärkeitä teknisiä askelia. Koulutuspo- liittisesti osaamismerkit ovat ensinnäkin osaamisen tunnistamisen ja tunnustamisen tekninen järjestelmä ja toiseksi jatkuvan oppimisen tukirakenne.

Tarkastelen jatkuvaa oppimista kansallisten merkkijärjestelmien kehityshankkeiden kautta. Valitsemani hankkeet kuvaavat, miten osaamismerkkityö on Suomessa edennyt pilotista kansalliseksi hallintamalliksi, konkreettisista osaamisista abstraktien ajattelun taitojen tunnistamiseen ja tunnustamiseen sekä oppilaitos- ja tutkintolähtöisestä koulutuksen kehittämisestä työelämälähtöiseen jatkuvaan oppimiseen.

\section{Ammatillisten opettajien osaamismerkit}

Oppiminen Online (http://www.oppiminenonline.com) on ammatillisille opettajille suunnattu pelillistetty osaamisen kehittämisohjelma digipedagogisen osaamisen päivittämiseen. Sen ovat kehittäneet Oulun ja Hämeen ammattikorkeakoulujen opettajakorkeakoulut ja Espoon seudun koulutuskuntayhtymä Omnia. Konseptia on kehitetty Osa Oppi -hankkeissa (Opetushallitus, OPH) vuodesta 2012 alkaen. Kokonaisuudessa on mahdollista saavuttaa yli 50 erilaista osaamismerkkiä, joiden peruste on osaamistavoitteesta muodostettu arviointikriteeri, ja hakijan sen mukaisesti osoittama osaaminen. Osaaminen kehittyy kolmella taitotasolla: Digi-Osaaja (10 merkkiä), Digi-Ekspertti (25 merkkiä) ja Digi-Kehittäjä (45 merkkiä).

Oppiminen Online hyödyntää yksinkertaisia pelillistämisen elementtejä (Deterding 2012). Kun täydennyskoulutus on käynnissä, verkkosivuilla on tulostaulu (leaderboard), josta selviävät ryhmien suoritukset ja viimeisimmät osaamismerkit reaaliajassa. Joukkuehenkeä kasvatetaan suljetussa Facebookryhmässä kannustamalla osaamismerkkien hakemiseen ja joukkueen ryhmäytymiseen. Kuukausittain eniten merkkejä ansainnut joukkue palkitaan. Osaamisen kehittämistä tukevat avoimet verkkomateriaalit ovat saatavilla ympäri vuorokauden. Oppiminen Onlinen tavoite on parantaa osallistujien digipedagogista osaamista, mutta ohjelmaan osallistuneista opettajista on tullut monesti myös osaamismerkkien kehittäjiä omissa organisaatioissaan sekä kansalli- 
Open MERKEISSÄ LUOTIIN

AMMATILLISEN OPETTAJAN

OPETTAJAOPINNOT JA

TYÖURAN KATTAVA

OSAAMISMERKISTÖ.

sissa ja kansainvälisissä hankkeissa (esim. Paronen 2020; CORE 2020).

Osaamismerkkien kehittämisen haasteita ovat alusta asti olleet merkkien laatu ja luotettavuus. Oppiminen Onlinen kehitysvaiheessa haasteeseen vastattiin osaamisperusteisella tasomallilla, joka perustui silloisiin Ope.fi-taitotasoihin ja Unescon (2011) kokoamaan opettajien tieto- ja viestintäteknisen osaamisen viitekehykseen.

Nykyiset Oppiminen Online -osaamismerkit perustuvat DigCompEdu-viitekehykseen (Redecker 2017). Oppiminen Onlinessa luotujen merkkien ja kokemusten perusteella on käynnistetty useita mittavia hankkeita kansallisten osaamismerkkijärjestelmien ja yhteisten käytänteiden kehittämiseksi. Yksi niistä on Open Merkit (OKM 2018-2020), jonka tavoite oli tukea ammatillisen koulutuksen reformiin sisältyvää opettajuuden muutosta ja osaamisen kehittämistä (Ruhalahti, Korhonen \& Niinimäki 2020). Mukana olivat kaikki ammatilliset opettajakorkeakoulut sekä Åbo Akademi ja Yrkesakademin ruotsinkielisestä opettajankoulutuksesta.

Open Merkeissä luotiin ammatillisen opettajan opettajaopinnot ja työuran kattava osaamismerkistö, jonka avulla voidaan valtakunnallisesti tunnistaa ja tunnustaa ammatillisten opettajien osaamista. Merkistössä on kuusi osaamisaluetta: arviointi, oppiminen ja ohjaus, työelämä ja verkostot, työyhteisö, kehittäminen ja moninaiset oppijat. Sen kehitys on ollut opetussuunnitelmiin, erilaisiin viitekehyksiin ja aiempaan kokemukseen pohjautuva prosessi (ks. esim. digipedagogiset merkit Kullaslahti, Ruhalahti \& Brauer 2019)

Open Merkit -hankeverkoston portaalissa (http://www.hamk.fi/openmerkit) ovat ohjeet kansalliseen koulutuksen järjestäjien yhteistoimin- taan ja ideoita ja ratkaisuja yhteisten materiaalien ja toimintatapojen tueksi. Verkostolla on yhteinen hallintamalli osaamismerkkien suunnittelun, jakamisen, arvioinnin ja edelleen kehittämisen tueksi sekä jaettu osaamismerkkitehdas (Open Badge Factory) arvioinnin ja merkkien myöntämisen laadun varmistamiseksi. Open Merkit ohjeistaa ensimmäisenä hankkeena kansallisten, eri koulutuksen järjestäjien yhteistoimintaan ja antaa käytännön ideoita ja ratkaisuja yhteisten materiaalien ja toimintatapojen tueksi.

\section{Perustaitojen varmistaminen eri kouluasteilla}

Osuvat taidot -hankkeessa (ESR 2019-2021) suunnitellaan ja pilotoidaan osaamismerkkejä tietotekniikkaa soveltavien ongelmaratkaisutaitojen (Kansainvälinen aikuistutkimus, PIAAC) kehittämiseen. Kansallinen osaamismerkkijärjestelmä mahdollistaa aikuisten tiedon käsittelyn ja hallinnan perustaitojen varmistamisen tunnistamalla ja tunnustamalla osaamista formaalin koulujärjestelmän ulkopuolella, eri kouluasteilla ja siirryttäessä koulutusmuodosta toiseen.

Hankkeen päätulos on osaamismerkistö, jonka eri tasot edustavat vaiheittain kehittyviä tietotekniikkaa soveltavia ongelmanratkaisutaitoja. Osaamistavoitteiden määrittely perustuu PIAAC-tutkimuksen linjauksiin sekä kansallisiin ja eurooppalaisiin suosituksiin perusosaamisesta ( $\mathrm{mm}$. Carretero, Vuorikari \& Punie 2017).

Kokonaisuus kuvaa konkreettisen rakenteen ammatillisten perustutkintojen opetussuunnitelmien perusteissa määrättyjen osaamistavoitteiden ja asetettujen kriteerien soveltamisesta digitaalisissa ympäristöissä. Merkkien suunnittelussa on otettu huomioon kansalaistaidot sekä yhä kasvava opiskelijajoukko, jonka äidinkieli on jokin muu kuin suomi. Osaamismerkkeihin sisältyvät arvioijan ohjeet auttavat opettajia huomioimaan erityisen tuen tarpeessa olevat oppijat. Ainutlaatuiseksi kokonaisuuden tekee osaamismerkkien tasomallin joustava rakenne, joka visualisoi työ- ja arkielämässä tarvittavan perusosaamisen, auttaa tunnistamaan ja tunnustamaan eli validoimaan eri tavoin hankittua osaamista myös 
vapaan sivistystyön organisaatioissa ja mahdollistaa näiden osaamisten edelleen hyväksymisen arvosanoilla arvioiduiksi suorituksiksi tutkintotavoitteisessa koulutuksessa. Merkkijärjestelmää pilotoidaan valtakunnallisesti, ja kokonaisuutta tarkennetaan pilottikokemusten perusteella. Osaamismerkit julkaistaan vuoden 2021 aikana Tietoyhteiskunnan kehittämiskeskuksen (Tieke) verkkosivulla (https:// tieke.fi/hankkeet/osuvat-taidot/).

Työelämäpedagogiikka korkeakoulutuksessa -hankkeessa (OKM 2018-2020), Oulun yliopiston Oppimisen ja koulutusteknologian tutkimusyksikkö (LET) pilotoi osaamismerkkejä arvioinnin menetelmänä osana kansainvälisten maisteriopiskelijoiden yhteisölliseen ongelmanratkaisuun keskittyviä opintokokonaisuuksia.

Problem Solving Case -opintojaksoja on toteutettu useita kertoja tiiviissä yhteistyössä vaihtuvien työelämäkumppaneiden kanssa, ja niissä hyödynnetään yhteisöllisen ongelmanratkaisun prosessimallia. Piloteissa opintojakson rakenne purettiin edelleen prosessimallin mukaiseksi kriteeripohjaiseksi osaamismerkistöksi. Kriteerityö keskittyi ajattelun ja tiedonrakentamisen taitojen sekä tavoitteellisen ryhmätyön kuvaamiseen ja jäsentämiseen sekä sitä kautta oppimisprosessin tukemiseen.

Osaamismerkkityö auttoi tarkentamaan opintokokonaisuuden sisältöä ja kuvaamaan etenkin sellaista osaamista, jota on muuten vaikea sanoittaa. Pilotissa sovellettiin osaamismerkein ohjautuvan oppimisen prosessimallia (Brauer 2019) ja erityisesti erilaisia tapoja arvioida osaamista merkein. Opintojaksojen työelämäkumppanit olivat mukana arvioimassa osaamismerkkejä, mikä vahvisti edelleen opintojen työelämäläheisyyttä. Työelämäedustajan myöntämä merkki on opiskelijalle arvokas osoitus saavutetusta osaamisesta työmarkkinoilla (Brauer, Siklander ym. 2020).

Kummankin ongelmaratkaisutaitoihin liittyvän pilotin tavoite oli auttaa sekä opiskelijoita että opettajia hahmottamaan osaamistavoitteet, arviointikriteerit ja osaamisen osoittaminen yhdenmukaisesti. Korkeakoulutuksesta saadut tulokset korostavat, että osaamismerkit sopivat myös muunlaisen osaamisen kuin teknisen taidon tai sen soveltamisen tunnistamiseen ja tunnustamiseen. Taitojen ja osaamisen vertailukelpoisuutta edistävät yhteiset koulutusten laajuutta kuvaavat käsitteet, kuten opintopisteet (ECTS tai ECVET), eurooppalainen tutkintojen viitekehys (EQF) ja ESCO-taitojen/osaamisen, pätevyyksien ja ammattien eurooppalainen luokitus (Pakanen 2020). ESCO on teknisesti suoraan liitettävissä Open Badge Factory -järjestelmässä suunniteltuihin osaamismerkkeihin.

Osaamismerkistöjen kokonaisuutta sekä merkkien ja merkistöjen keskinäisiä suhteita tarkastelemalla on mahdollista suunnitella, kehittää ja toteuttaa jatkuvaa oppimista yli tutkinto- ja oppilaitosrajojen. Perustaitojen varmistamiseen liittyvien pilottien kokonaisuutta tarkastelemalla voidaan tulevaisuudessa kuvata ja tutkia yhä laajemmin koulutuksen rakenteita ja työelämävastaavuutta eri kouluasteilla. Pilotit auttavat kehittämään sujuvia siirtymiä kouluasteelta toiselle ja luovat uusia näköaloja ja käytänteitä oppilaitosrajat ylittävään yhteistyöhön.

\section{Osaamismerkkien työelämälähtöinen kehittäminen}

Kun työn sisällöt ja työn tekemisen tavat muuttuvat, on osaamisen kehittämistä kohdennettava, jos työllisyysastetta halutaan nostaa (OKM 2020). Yksi kasvualoja on peliala, jolle tyypillisesti työllistytään jopa itseoppineena, mutta alalle myös koulutetaan runsaasti osaajia ammatillisella toisella asteella, ammattikorkeakouluissa ja yliopistoissa. Metropolia Ammattikorkeakoulun koordinoiman Osaamisen pelimerkit -hankkeen (ESR 2017-2020) tavoite oli tehdä pelialan osaamista näkyväksi sekä helpottaa siirtymiä koulutusasteilta toisille ja edelleen työelämään. Hankkeella haluttiin nostaa esiin tasokasta pelialan koulutusta ja tukea opiskelijoiden verkostoitumista jo opiskeluaikana sekä keskenään että alan yritysten kanssa.

Osaamisen Pelimerkeissä pelialan eri ammateissa tarvittava osaaminen kuvataan valtakunnallisena osaamismerkistönä, joka kattaa eri kouluasteilla ja työelämässä saavutettavissa olevan osaamisen (Heinonen 2020). Osaamiset kuvataan osaamismerkki- 


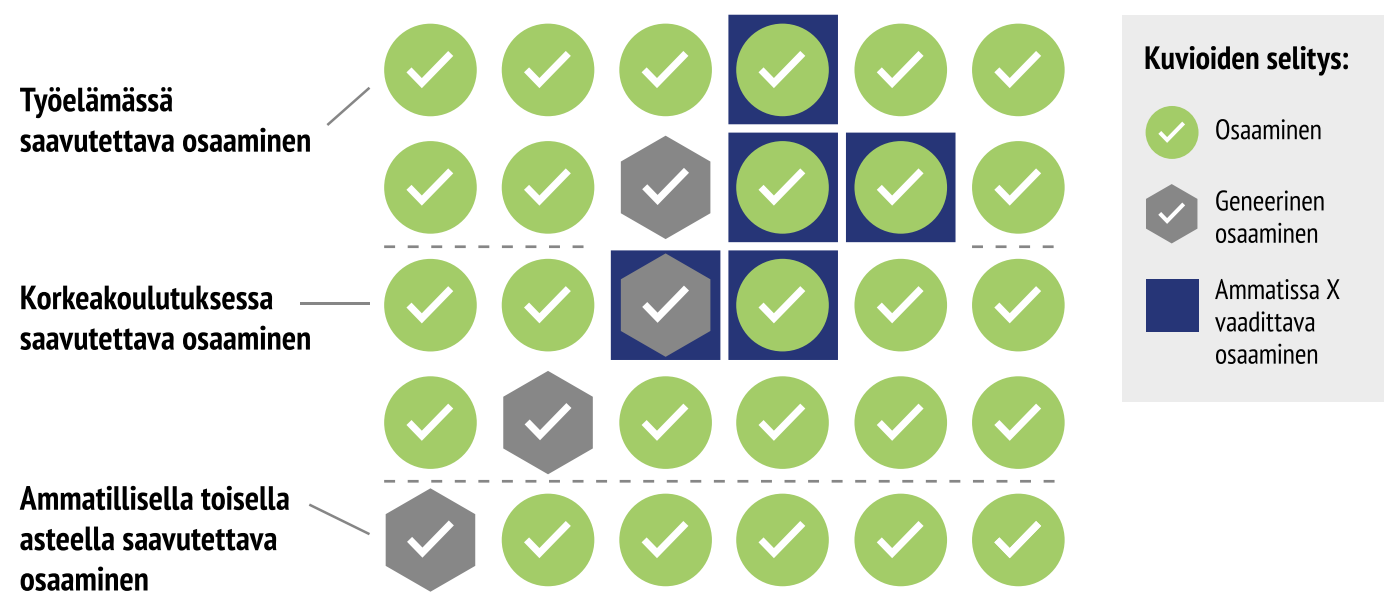

Kuvio 1. Työelämässä tarvittavan osaamisen saavuttaminen eri tavoin.

järjestelmässä työtehtävittäin osaamistavoitteiden, arviointikriteerien ja erilaisten osaamisen todentamisen tapojen avulla (kuvio 1).

Osaamismerkistö kuvaa työelämän rakennemuutoksesta nousevia osaamistarpeita ja kokonaan uusia osaamisia. Pelitalojen kanssa luotu osaamismerkistö sopii eri tavoin hankitun osaamisen tunnistamisen ja tunnustamisen työkaluksi pelialalla ja auttaa oppilaitoksia kehittämään työelämäläheistä koulutusta yhdessä alan toimijoiden kanssa. Osaamismerkistössä alan työtehtävät kuvataan yhtenäisten, työelämän todellisista tarpeista kumpuavien osaamistavoitteiden ja arviointikriteerien avulla. Osaamiskuvaukset käsittävät sekä ammatillisen että geneerisen osaamisen. Osaamismerkit auttavat näin suunnittelemaan henkilökohtaisia polkuja kohti toivottua osaamista ja kertovat alan opiskelu- tai työpaikkaa hakevan taidoista selkeämmin kuin koulutodistus.

Työelämälähtöinen näkökulma oppimisprosessiin on tuore ja herättää miettimään, miten oppilaitos- tai tutkintolähtöinen koulutuksen kehittäminen vastaa työelämän osaamistarpeisiin jatkuvan oppimisen näkökulmasta. Koulutuksen järjestäjienkin rooli muuttuu, kun eri tavoin hankitulle osaamiselle voi saada tunnustusta yhä yksinkertaisemmin.

Esimerkiksi vapaa sivistystyö voi tulevaisuudessa olla merkittävä kouluttaja, joka mahdollistaa vaikkapa ainutlaatuisten käsityötekniikoiden opiskelun osana korkeakoulututkintoa tai kielitaidon vahvistamisen uutta työpaikkaa varten. Uutta tässä ei ole vapaan sivistystyön koulutuksista saatava monipuolinen osaaminen, vaan osaamisperusteiset osaamiskuvaukset ja osaamisen validointia tukevat ratkaisut, kuten osaamismerkit. Käytänteiden ansiosta saavutettu osaaminen on mahdollista liittää osaksi laajempia osaamiskokonaisuuksia. Lisäksi ne mahdollistavat tiedon hallinnoinnin ja teknisesti siirtämisen esimerkiksi kansalliseen Koski-tietovarantoon, joka sisältää valtakunnallisia perusopetuksen, lukiokoulutuksen ja ammatillisen koulutuksen opintosuoritus- ja tutkintotietoja. Merkit ovat kuitenkin uusi asia ja herättävät paljon kysymyksiä: Pitääkö kaikkea osaamista arvioida? Kuka on kelpoinen arvioimaan? Paljonko arviointi lisää työtä? Entä kuka työn maksaa?

\section{OSAAMISMERKKIJÄRJESTELMIEN TULEVAISUUDEN KEHITYSLINJOJA}

'Osaamisperusteisuus' liitetään käsitteenä usein vain ammatilliseen koulutukseen ja sen tuottamiin käytännön taitoihin. Osaamismerkkityö on kuitenkin tuonut yhteen toimijat eri koulutussektoreilta ja avannut uusia näkymiä suunnitella ja toteuttaa tutkinto- ja oppilaitosrajat ylittävää koulutusta taloudellisesti ja tehokkaasti. Merkit ovat vaikuttava kriteeriperusteinen oppimisratkaisu, joka sitoo yhteen erilaiset oppimisyhteisöt ja vaihtoehtoiset tavat hankkia osaamista (Knight \& Casilli 2012). 
Globaalisti osaamismerkkien kehittämisen keskeinen ajatus on tasa-arvoiset mahdollisuudet jatkuvaan oppimiseen (Open Recognition Alliance 2020). Merkit lisäävät opiskelijan motivaatiota uudistua yksilöllisissä ja yhteiskunnallisissa muutostilanteissa (Brauer 2019). Kun kokonaisuuden suunnittelussa huomioidaan kansalaistaidot ja tuotetaan kielellisesti selkeää aineistoa, merkit vastaavat myös koulutuspoliittiseen tavoitteeseen tukea maahanmuuttajia ja niitä, joilla on heikot perustaidot (OKM 2020).

Osaamismerkit ovat yksi mahdollisuus tukea jatkuvan oppimisen rakenteita, osaamisen systemaattista kehittämistä ja edistää digitalisaatiota - pedagogiikka edellä (Tammilehto 2020). Koulutus- ja työvoimapolitiikan näkökulmasta ne avaavat käytännössä vaihtoehtoja jatkuvan oppimisen digitaalisen ekosysteemin palvelukehitykseen (OKM 2020). Teknologisesti osaamismerkit antavat mallin testata ja kehittää avointa ohjelmointirajapintaa hyödyntäviä sovelluksia. Lisäksi suomalaiset hankkeet pilotteineen ovat merkittäviä avauksia digitalisaation mahdollistamista pedagogisista sovelluksista, jotka perustuvat vahvaan osaamisperusteisuuden osaamiseen ja tuoreeseen tutkimukseen.

Osaamismerkkien avulla kehitetään joustavaa koulutustarjontaa vastauksena sekä tunnistettuihin osaamisvajeisiin että elinikäiseen oppimiseen (OECD 2020). Vuonna 2020 tutkintojen pienet osakokonaisuudet (microcredentialing) ovat yksi koulutuksen painopisteistä Euroopan komission vuotuisessa työsuunnitelmassa. Osaamismerkit ovat siihen yksi väline, mutta niiden kehittäminen ja käyttöönotto kytkeytyy lisäksi uudistuviin arvioinnin menetelmiin ja yhteiseurooppalaisiin osaamisjärjestelmiin, kuten ESCO (Euroopan komissio 2020) ja Europass
(Cedefop 2020). Yhteiseurooppalaiset linjaukset auttanevat ratkomaan merkkien kehittämisessä koettuja haasteita, kuten merkin hakijan tai myöntäjän identiteetin todentaminen tai arviointikriteerien ja -prosessin laadunvarmistus (MICROBOL 2020).

On tärkeää luoda ja vakiinnuttaa yleiset ja yhteiset pelisäännöt, joilla osaamismerkkejä käytetään ja kehitetään. Näin niiden arvo on todellinen merkin saajalle, merkin avulla osaamista tunnistavalle oppilaitokselle tai työelämän edustajalle. Koulutuksen tehtävä on kohottaa osaamista, ja vaikka yhteiset linjaukset ja tekniset ratkaisut ovat käytännön tuotoksia, teknisen kehittämisen lisäksi on tuettava osaamismerkkeihin ja oppimiseen liittyvää tutkimus- kehitys- ja innovaatiotyötä. Jos haluamme luoda uudenlaista jatkuvan oppimisen huippuosaamista, tarvitaan rakenteiden uudistamista tukevaa poliittista päätöksentekoa, yhteistä kansallista tahtotilaa sekä lisää tutkimusta osaamisperusteisuudesta, osaamismerkeistä ja oppimisesta eri kouluasteilla ja työelämässä.

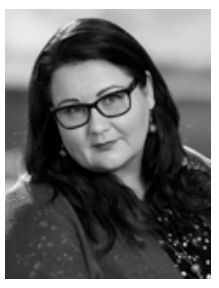

SANNA BRAUER

$\mathrm{KT}, \mathrm{AmO}$, lehtori ammatillinen opettajakorkeakoulu Oulun ammattikorkeakoulu oppimisen ja koulutusteknologian tutkimusyksikkö LET Oulun yliopisto

(i) https://orcid.org/0000-00025303-6600

Näkökulmateksti perustuu Sanna Brauerin kasvatustieteen väitöskirjaan Digital Open Badge-driven Learning - Competence-based Professional Development for Vocational Teachers (2019) sekä tutkimusja kehittämistyöhön osaamismerkein ohjautuvasta oppimisesta.

\section{LÄHTEET}

Billett, S. (2001). Knowing in Practice: Re-conceptualising Vocational Expertise. Learning and Instruction. 11, 431-452. DOI: 10.1016/S0959-4752(00)00040-2.

Brauer, S. (2019). Digital Open Badge-driven Learning - Competence-based Professional Development for Vocational Teachers. Väitöskirja. Acta Universitatis Lapponiensis 380. Rovaniemi: Lapin yliopistopaino.

Brauer, S., Kettunen, J., \& Hallikainen, V. (2018).

\footnotetext{
"Learning Online" for Vocational Teachers Visualisation of Competence-based-approach in Digital Open Badge-driven Learning. Ammattikasvatuksen aikakauskirja 20(2), 13-29.

Brauer, S., Pajarre, E., Nikander, L., Häkkinen, R., \& Kettunen, J. (2020). Kehittämishankkeet korkeakoulutuksen työelämärelevanssin edistäjänä. Ammattikasvatuksen aikakauskirja 22(1), 8-25.
} 
Brauer, S., Siklander, P., Impiö, N., \& Vuopala, E. (2020). Osaamismerkit arvioinnin menetelmänä uutta ajattelua opetussuunnitelmiin. Teoksessa A. Virtanen, P. Tynjälä, \& J. Helin. Työelämäpedagogiikka korkeakoulutuksessa. Jyväskylä: Jyväskylän yliopistopaino.

Carretero, S. Vuorikari, R. \& Punie, Y. (2017). DigComp 2.1 The Digital Competence Framework for Citizens with Eight Proficiency Levels and Examples of Use. EU Publications. DOI: 10.2760/38842.

Cedefop (2020). New Europass. https://europass. cedefop.europa.eu/new-europass.

CORE (2020). Key Action 3 (KA3) CORE - Cooking for the future project. Badge Finland Webinar 14.5.2020. https://cookingforthefuture.net/2053-2/.

Deterding, S. (2012). Gamification: designing for motivation. Interactions 19(4), 14-17.

Ellström, P. E. (1997). The Many Meanings of Occupational Competence and Qualification. Journal of European Industrial Training 21(6/7), 266-273. DOI: 10.1108/03090599710171567.

Euroopan komissio (2020). ESCO - Taitojen/osaamisen, pätevyyksien ja ammattien eurooppalainen luokitus. https://ec.europa.eu/esco/portal/home.

Heinonen, S. (2020). Osaamisen tunnistaminen osaamismerkeillä - pelialan osaamistavoitekartta. https://pelimerkit.metropolia.fi/2020/06/04/ osaamisen-tunnistaminen-osaamismerkeilla-pelialanosaamistavoitekartta/.

Knight, E., \& Casilli, C. (2012). Mozilla Open Badges. In Game Changers. Education and information technologies. EDUCAUSE, 279-284. https://net. educause.edu/ir/library/pdf/pub7203cs6.pdf.

Kullaslahti, J., Ruhalahti, S., \& Brauer, S. (2019). Professional Development of Digital Competences: Standardised Frameworks Supporting Evolving Digital Badging Practices. Journal of Siberian Federal University. Humanities and Social Sciences 12(2), 175-186. DOI: 10.17516/1997-1370-0387.

MICROBOL (2020). Micro-credentials linked to the Bologna Key Commitment. Desk Reseach Report September 2020. https://www.eua.eu/downloads/ publications/microbol\%20desk\%20research\%20 report.pdf.

OECD (2020). The Emergence of Alternative Credentials. Education Working Paper No. 216 Organisation for Economic Co-operation and Development Directorate for Education and Skills. http://www. oecd.org/officialdocuments/publicdisplaydocumentpd $\mathrm{f} /$ ?cote $=$ EDU $/$ KKP(2020)4\&docLanguage $=$ En .
Oosi, O., Jauhola, L., Rausmaa, S., \& Haila, K. (2020). Miten osaaminen näkyväksi? Kartoitus osaamisen tunnistamisen ja tunnustamisen rakenteista ja käytännöistä Suomessa ja valituissa kansainvälisissä verrokkimaissa. Työ- ja elinkeinoministeriön julkaisuja 2020:28. http://urn.fi/URN:ISBN:978-952-327-561-4.

Open Badges Community (2020). What are Open Badges? https://openbadges.org/.

Open Recognition Alliance (2020). https://www. openrecognition.org/.

OKM, opetus- ja kulttuuriministeriö (2019). Jatkuvan oppimisen kehittäminen, työryhmän väliraportti. Opetus- ja kulttuuriministeriön julkaisuja 2019:19. http://urn.fi/URN:ISBN:978-952-263-641-6.

OKM, opetus- ja kulttuuriministeriö (2020). Parlamentaarinen jatkuvan oppimisen uudistus: Jatkuvan oppimisen palvelujärjestelmän uudistusosaamisella työllisyyttä. Kehittämisen suuntaviivat. https://minedu.fi/jatkuva-oppiminen.

Pakanen, L. (2020). Filled with Skills. Teoksessa R. Duvekot, A. Karttunen, M. Noack ja L. Van den Brande (toim.) Making Policy Work - Validation of Prior Learning for Education and the Labour Market. Series VPL-Biennale nr. 7. ss. 67-73. European Centre Valuation of Prior Learning \& Bertelsmann Stiftung. Houten/ Berlin. https://ec-vpl.nl/download/entry/162/.

Paronen, L. (2020). Badgeverse, vapaan sivistystyön villikortti. Badge Finland. https://badgefinland.fi/ badgeverse-vapaan-sivistystyon-villikortti .

Redecker, C. (2017). European Framework for the Digital Competence of Educators: DigCompEdu. Punie, Y. (Ed.). EUR 28775 EN. Publications Office of the European Union, Luxembourg. DOI: 10.2760/159770.

Korhonen, A.-M., Ruhalahti, S. \& Niinimäki, J. (2020). Finnish Vocational Teachers' Competences Made Visible by Open Badges. Journal of Higher Education Theory and Practice 20(6). DOI: 10.33423/jhetp. v20i6.3138.

Tammilehto, M. (2020). Opetus- ja kulttuuriministeriön puheenvuoro Merkillistä, merkityksellistä vai merkittyä? -osaamismerkit osaamista kehittämässä -seminaarissa 11.2.2020 [video]. https://video. haaga-helia.fi/media/Mika+Tammilehto++Openmerkit/0_82w2nnfy.

Unesco (2011). UNESCO ICT Competency Framework for Teachers. http://unesdoc.unesco.org/ images/0021/002134/213475e.pdf. 